The University of San Francisco

USF Scholarship: a digital repository@ Gleeson Library |

Geschke Center

1993

\title{
Markets and States in Development: India's Reformers and the East Asian Experience
}

Shalendra Sharma

University of San Francisco, sharmas@usfca.edu

Follow this and additional works at: http://repository.usfca.edu/pols

Part of the Economics Commons, Law and Politics Commons, and the Political Science Commons

\section{Recommended Citation}

Shalendra D. Sharma. Markets and States in Development: India's Reformers and the East Asian Experience. Asian Survey Vol. 33, No. 9 (Sep., 1993), pp. 894-904

This Article is brought to you for free and open access by the College of Arts and Sciences at USF Scholarship: a digital repository @ Gleeson Library | Geschke Center. It has been accepted for inclusion in Politics by an authorized administrator of USF Scholarship: a digital repository @ Gleeson Library | Geschke Center. For more information, please contact repository@usfca.edu. 


\section{MARKETS AND STATES IN DEVELOPMENT}

\section{India's Reformers and the East Asian Experience}

\section{Shalendra D. Sharma}

In his inimitable manner, Manmohan Singh, India's self-effacing finance minister, is fond of rhetorically asking: "What does South Korea have that India doesn't?" or "Why have we [India] been marginalized if in 1960, South Korea and India had roughly the same per capita income . . . but today Korea has a strong economy and our economy faces severe problems?" 1 Such hard, self-searching questions are at the heart of the current debate on economic reform-"liberalization"-in India. In spite of the fact that both these countries faced similar economic problems and developmental challenges in the 1950s, South Korea in a span of some two decades has transformed itself into the proverbial Asian "tiger"-aggressive, sleek, and confident-while India after four decades of state-guided or "planned development" has continued to lag behind as the lame elephant-immense, lethargic, and seemingly lumbering into obscurity.

Singh's frequent reference to the divergent macroeconomic performance of these two countries is no accident. Repeatedly comparing South Korea, the paradigmatic East Asian success story, with the crisis-ridden and economically troubled Indian subcontingent, and unequivocally declaring that his government's economic policies make an explicit break with the failed dirigiste policies of the past is not only designed to illustrate the shortcomings of the Indian model of development but is also a calculated political move. The comparison forcefully underscores the significance of the gov-

Shalendra D. Sharma is Assistant Professor of Politics, University of San Francisco. The author wishes to thank Jonathan Barker, Nanda Choudhry, and Richard Sandbrook for helpful comments on a draft of this article.

(C) 1993 by The Regents of the University of California

1. Economist, May 23, 1991, p. 21, and India Today, July 31, 1991, pp. 24-25. 
ernment's economic liberalization programs and is intended to pull the rug out from under the feet of critics who accuse the government, and the finance minister in particular, for "selling out India's sovereignty" to the World Bank and the International Monetary Fund.

While the Indian government's economic liberalization initiatives and its willingness to learn from countries once dismissed as "lackeys of western imperialism" is a welcome change, it should also be noted that emulating success by following in the footsteps of others is neither easy nor a guarantee that the pilgrimage will lead to the promised land. Indeed, comparative scholarship shows that East Asia's particular historical, political, socioeconomic, and cultural conditions are not easily transferred and that the East Asian "model" is not likely to be replicated widely. Therefore, sanguine claims by the leading advocates of India's liberalization-who include not only converts such as the finance minister but also the ascendant academics-cum-technocrats sympathetic to monetarist and neoclassical economics now acting as policy interlocutors-that they are following the "time-tested" path of the East Asian NICs, and that India's own "economic miracle" is just around the corner sound surprisingly optimistic. ${ }^{2}$ While there is doubtless an element of political calculation and bravado in such assertions, I will argue that in large part this optimism stems from an incomplete, if not superficial understanding of the East Asian experience. Specifically, the pervasive belief that the secret of the East Asian miracle was (and is) their market-oriented development strategy is fundamentally flawed because it fails to take into account the role of the interventionist state in guiding economic development. ${ }^{3}$ In presenting a more nuanced picture of the East Asian experience, this article not only provides a much needed corrective to the gaps and the problematic in the Indian debate, but also outlines a more balanced set of "lessons" that countries like India can draw from the East Asian experience.

\section{The Balance Sheet}

While on one hand, post-independent India's overall economic performance has been impressive when compared to the nearly stagnant growth during the colonial period, its record is disappointing when compared to growth levels achieved by several other developing countries. For example, India's gross domestic product (GDP) in the manufacturing and in-

2. For example, see Jagdish Bhagwati, "Is India's Economic Miracle at Hand?" New York Times, June 9, 1985; Alan Heston, "India's Economic Reforms: The Real Thing," Current History, March 1992.

3. It is important to note that sophisticated neoclassical analysts do not necessarily neglect the role of the state, but tend to view its roles and functions as minimal, approximating those prevailing in a free-market situation. The East Asian experience challenges such a view. 
dustrial sectors stuck at the perennial "Hindu rate of growth" of $3.5 \%$ during the period 1950-84, ${ }^{4}$ lagging far behind the "hyper" $9 \%$ to $15 \%$ rates achieved by countries like South Korea, Taiwan, Brazil, Malaysia, Mexico, Indonesia, and Thailand. In fact, according to a leading economist, India's "share of manufacturing in real GDP has stagnated at about $15 \%$ for more than a decade . . . and the only sectors that have grown relatively rapidly in recent years are public administration and defense."5

In per capita terms, India's growth rate has also fallen behind. Average incomes in South Korea, once roughly equivalent to those in India, are currently ten times greater and are more equitably distributed. It is not unreasonable to assume that most of India's poor would have been substantially better off, even if the benefits of growth were inequitably distributed, had India's GDP grown as rapidly as that of South Korea and the other NICs. Similarly, India's share of world exports, both commodity and manufactured, steadily declined from about $2.5 \%$ in the early 1950 s to less than $0.5 \%$ in the late 1980 s. While South Korea's exports of manufactured goods in 1960 were negligible, India exported goods totaling just over $\$ 600$ million; but by the mid-1980s, India's exported industrial goods were worth just over $\$ 5$ billion compared to South Korea's $\$ 24.5$ billion, Hong Kong's \$21.9 billion, Singapore's \$21.8 billion and China's \$22.2 billion. ${ }^{6}$

Eventually, India's laggard economic performance coupled with its technologically obsolete, high-cost industry began to impinge severely on the national economy causing unprecedented macroeconomic imbalances and inflationary pressures with serious, negative reverberations on incomes, domestic interest rates, prices, and the balance of payments. So deep were the fiscal problems that despite respectable growth rates in the mid-1980s, the real value of incomes was being rapidly eroded by rising inflation, and deficit-financing (to offset the decline) by high-cost foreign borrowing only made matters worse. By the late 1980s, India's external deficit was at a high of $3.4 \%$ of its GDP. This was reflected in declining foreign exchange reserves that fell to US $\$ 1.1$ billion-equivalent to about

4. Even while India's GDP in manufacturing reached an average $5.3 \%$ growth in the mid1980s, it still lagged behind the rates recorded by the East Asian NICs. See World Development Report 1991 (Washington, DC: The World Bank, 1991).

5. T. N. Srinivasan, "The Economy: Stresses, Strains and Opportunities," in India Briefing 1988, Marshal Bouton and Philip Oldenburg, eds. (Boulder, Colo: Westview Press, 1988), p. 31.

6. World Bank, World Development Report 1990; Deena Khatkhate, "National Economic Policies in India," in National Economic Policies, Dominik Salvatore, ed. (New York: Greenwood Press, 1991), pp. 231-76. 
three weeks of imports-and brought India to the brink of defaulting on foreign loans in 1991.

\section{What Went Wrong and the Way Out}

While there is a growing body of literature providing many explanations for India's slow economic growth, and industrial growth in particular, ${ }^{7}$ there is general consensus that the current problem is rooted in the early post-independence period - the beginning of the planning process. ${ }^{8}$ The proponents of economic liberalization argue that under the guise of "planned economic development" the central government, through its control of the "commanding heights" of the economy, erected an elaborate maze of corporatist structures, quantitative regulations, and "control instruments" until it incrementally permeated all levels of the public and private sector, creating one of the most comprehensively controlled and regulated economies in the noncommunist world. This "pernicious system," labeled the "license-permit raj" by its critics, was purposely structured to facilitate central planning and command mandates rather than market responses. It did so by granting arbitrary powers to a hierarchy of bureaucrats and politicians, which spawned wasteful rent-seeking activities and in the process stifled competition and undermined innovation, production, and efficiency.

Moreover, policy-induced distortions such as protectionist trade policies and overvalued exchange rates and the general impotence of state directed macroeconomic policies contributed to industrial concentration and stagnation, allowing the state and vested interests not only to capture a disproportionate share of the public largess and profits but also to divert and waste scarce resources on speculative ventures and unproductive activities. Jagdish Bhagwati, one of the leading advocates of liberalization, aptly sums up the sad legacy of India's regulatory state:

7. See Isher J. Ahluwalia, Industrial Growth in India: Stagnation Since the Mid-Sixties (New Delhi: Oxford University Press, 1985); Pranab Bardhan, The Political Economy of Development in India (Oxford: Basil Blackwell, 1984); M.R. Bhagavan, "A Critique of India's Economic Policies and Strategies," Monthly Review, July 1987; P.N. Dhar, Constraints on Growth: Reflections on the Indian Experience (New Delhi: Institute of Economic Growth, 1990); Bimal Jalan, India's Economic Crisis: The Way Ahead (Delhi: Oxford University Press, 1991); Baldev Raj Nayar, India's Mixed Economy: The Role of Ideology and Interest in its Development (Bombay: Popular Prakashan, 1989); I.J. Patel, "On Taking India into the Twenty-First Century," Modern Asian Studies, 21:2 (1987), and "New Economic Policies: A Historical Perspective," Economic and Political Weekly 27:1 (January 1992).

8. Even prominent central planners like Bimal Jalan, who have been at the center of India's financial bureaucracy for some three decades, now admit to this. In India's Economic Crisis, Jamal writes that they "did not pay adequate attention to the real determinants of state action, nor to the economic consequences of excessive bureaucratic intervention" (p. 11). 
The Indian regime of controls spawned its own interests. The entire society it yielded, with entrepreneurs enjoying squatter rights, created a business class that wanted liberalization in the sense of less hassle, not genuine competition. The bureaucrats ... could not but have noticed that this regime gave them the enormous power that the ability to confer rents generates. The politics of corruption also followed as politicians became addicted to the use of licensing to generate illegal funds for election and for themselves. The iron triangle of business, bureaucrats, and politicians was born around the regime. ${ }^{9}$

The champions of economic reform argue that in order to escape the deleterious effects of central planning and modernize India's economy, the government's sphere should be reduced to the minimum, and that autarkic regulations, bureaucratic controls, and diktats be replaced by market mechanisms. Specifically, the call is for:

- liberalization of the economy in order to allow production, prices, interest rates, and wages to find their "natural equilibrium" through the interaction of supply and demand;

- deregulation of financial markets and the opening up of restricted sectors of the economy to private investment;

- the dismantling of restrictive legislation such as direct and indirect taxation;

- the privatization of state-owned enterprises (SOE) and the liquidation of nonviable ("sick") firms and SOEs;

- complete dismantling of the industrial licensing system and foreign exchange controls.

Such a market-conforming, export-oriented, outward-looking strategy, the reformers argue, will enable the economy to move toward an equilibrium, i.e., balanced, growth path in which patterns of production, investment, and capacity creation follow dynamic comparative advantage and thereby minimize resource costs, increase competition in domestic markets, and eliminate potential channels of corruption. Indeed, in spite of the halfhearted nature of economic liberalization in India, many features of these new reform policies have already been introduced, especially by the Narasimha Rao administration.

\section{Neoclassical Political Economy and East Asia}

As noted earlier, these arguments for economic liberalization and marketoriented reforms have been motivated in no small measure by a particular reading of the East Asian experience. According to the advocates of India's liberalization, East Asia's economies "took off" because the "mini-

9. Jagdish Bhagwati, "Poverty and Public Policy," World Development 5 (May 1988), p. 36. 
malist states" employed only limited fiscal or monetary instruments and followed consistent and coherent market-conforming policies such as trade liberalization, devaluation, a pragmatic stance toward foreign direct investment, and a willingness to allow international market forces to determine price relativities (including exchange rate adjustments). Thus, they were able to offset externalities and ensure that resources would be utilized efficiently and allocated in accordance with the principles of comparative advantage. The reform advocates point out that South Korea and Taiwan, whose economic structures were once typical of many developing countries, by following market signals were able to make the shift from importsubstitution industrialization (ISI) in the 1950s and 1960s to export-promotion by the late 1960s. Countries like India, on the other hand, following orders from managers of the command economy, only aggravated economic distortions, turning businesses and industries into pro-protectionist lobbies and entrenching rent-seeking activities. To the reformers, the East Asian NICs are a living example of how the benign "invisible hand" of the market can enhance economic growth with efficiency and equity simultaneously.

However, comparative studies, including those by scholars sympathetic to neoclassical claims, ${ }^{10}$ reveal that East Asia's rapid economic growth and the relatively egalitarian pattern of income distribution cannot be attributed to market-oriented policies alone, but rather rests as well on a combination of peculiar initial conditions and strategic government interventions. First, the smooth transition from ISI to export promotion was not simply the result of market signals, but benefited from an earlier period of business and entrepreneurial maturation which dated back to the pre1945 period under the Japanese in Korea and Taiwan. ${ }^{11}$

Second, while it is true that, with the exception of Hong Kong, East Asia's impressive performance with respect to income equity is due to its rapid expansion in labor-absorbing, export-oriented manufacturing industries, it should be noted that the socioeconomic structure and patterns of income distribution in South Korea and Taiwan were relatively egalitarian even before the transition to export-led growth. This was due in large part

10. For example, Leroy Jones and I. Sakong, Government, Business and Entrepreneurship in Economic Development: The Korean Case (Cambridge: Harvard University Press, 1980); Sung-Tae Ro, "National Economic Policies in Newly Industrialized Countries," in National Economic Policies, Dominik Salvatore, ed. (New York: Greenwood Press, 1991), pp. 171-204.

11. See discussion by Bruce Cumings, "The Origins and Development of the Northeast Asian Political Economy: Industrial Sectors, Product Cycles and Political Consequences," in The Political Economy of the New Asian Industrialism, Frederic C. Deyo, ed. (Ithaca, N.Y.: Cornell University Press, 1987). 
to the extensive business/commercial restructuring and agrarian reforms that were undertaken in these countries in the 1950s. ${ }^{12}$ Third, what the neoclassical accounts most frequently overlook is that the activist East Asian states went far beyond the prescribed neutral policy advocated by these theorists. The market-oriented policies were accompanied by strategic state intervention that complemented and directed rather than negated market forces.

Specifically, despite variations in the pattern of state intervention, in each case the East Asian states through discrete and targeted interventions created an environment supportive of market forces. For example, in the early phase the state acted as a surrogate for missing capital markets by procuring domestic savings and foreign investment and protecting infant domestic industries, and later it played a key role in identifying potentially lucrative niches within the global economy and orchestrating with alacrity incentives to encourage domestic firms and export cartels to invest and modernize. Moreover, by following market signals, the state was able to respond (often preemptively) to externalities, provide crucial market information, and broker relations with foreign investors and creditors.

By assuming a catalytic role in the areas of information processing and technology acquisition, the state was able to foster local mastery, rather than simply transfer of modern technologies, and throughout the different stages of modernization it provided the infrastructure needed by industry and business. Finally, by heavily investing in education (especially vocational training), it created a technically skilled and disciplined labor force, which is indispensable to economic modernization and export-promotion in particular.

The Developmental State and Economic Development Comparative scholarship has shown that capitalist modernization has historically required some sort of an alliance between the state and the emerging bourgeois classes, and particularly in the case of "late bloomers." Alexander Gerschenkron in his classic Economic Backwardness in Historical Perspective pointed out that "late industrializers" confronting an established, competitive, and hegemonic international industrial order faced complex problems of economic development and hence required direct state intervention to overcome political and economic impediments. In Germany, for instance, industrialization was spearheaded by an alliance

12. Robert Wade, Governing the Market: Economic Theory and the Role of Government in East Asian Industrialization (Princeton, N.J.: Princeton University Press, 1990); G. Ranis and S.W. Kuo, Growth with Equity: The Taiwan Case (London: Oxford University Press, 1979). 


\section{SHALENDRA D. SHARMA 901}

led by a strong "interventionist state" and private banking and industrial capital. In this setting, the state not only harnessed the resources for industrialization but also assumed firm political control over the dominant economic interests and a directive, coordinating role in economic management and decision-making. Similarly, Chalmers Johnson in his pathbreaking study on MITI provides an excellent account of an "autonomous developmental state" in action. According to Johnson, the Japanese state's "embedded autonomy" exemplified by its institutionalized and centralized decision-making structures, its emphasis on "performance" and "plan-rational" technocratic solutions, and the "existence of a powerful, talented, and prestige-laden economic bureaucracy" allowed the state to act as a surrogate for weak indigenous capitalism, set "substantive social and economic goals," and implement a strategy of development based on "industrial rationalization." 13

The "embedded autonomy" of the Chiang regime in Taiwan and the Park and Chun regimes in South Korea enabled them also to achieve a relatively high degree of insulation from the dominant interests in civil society. According to specialists analyzing these developmental states, ${ }^{14}$ an elaborate corporatist organization of interest groups-a strategy that granted considerable operational space to market-oriented technocratscum-policy elites and allowed paternalistic collaboration with powerful business interests in the private sector-enabled these states to pursue market-conforming methods of state intervention in the economy without precipitating organized opposition from powerful vested interests. Moreover, their well-trained, efficient, and "meritocratic bureaucracy," a product of the "hard" state's "business-like" institutional and decision-making structures, reduced intrabureaucratic logrolling and conflict, while the corporate control of labor enabled the state to co-opt and subordinate groups from the popular sector.

More recently, Robert Wade has provided new insights into these issues. ${ }^{15}$ In sharp contrast to neoclassical accounts, Wade articulates an alternative or "governed market" theory that argues it is the "pragmatic synergy" between East Asian governments and markets that explains their economic and developmental success. Focusing on Taiwan, but with comparisons to South Korea, Japan, and Hong Kong, Wade provides detailed accounts of how these states have utilized their policy instruments to maintain macroeconomic growth and stability and spearhead export-promoting industrialization. Painstakingly tracing the states' role in different

13. Chalmers Johnson, MITI and the Japanese Miracle: The Growth of Industrial Policy, 1925-1975 (Stanford, Calif.: Stanford University Press, 1982), esp. pp. 17-18, 25.

14. Frederic C. Deyo, ed., Political Economy.

15. Robert Wade, Governing the Market. 
industries and sectors over time, Wade shows how East Asian governments encouraged both high levels and sectoral composition of investment that could not have been supplied by the market. He provides a detailed account of the "trade regime"- the core of the neoclassical account of export-led growth-arguing that although exporters enjoyed a free trade regime for inputs, the domestic market for final products was protected by governmental regulations well into the mid-1980s, and that exporters were granted supports that went far beyond a favorable exchange rate. Through case studies and exhaustive reviews of the instruments of government policy, Wade vividly demonstrates how market-guided state intervention has been central to the economic success of East Asia. These interventions included mobilizing domestic and foreign savings for "productive investments," targeting lucrative niches within the global economy, providing incentives to ensure technological and financial innovations, and deliberately responding to market signals in order to allow firms to minimize risk and exploit comparative advantage.

\section{The Lessons for India}

This review of the East Asian experience provides some useful lessons for India and other countries attempting economic reform. Most notably, market-oriented development and state intervention must be viewed as complementary rather than competing or contradictory. The East Asian cases suggest that an efficiently functioning market economy rests critically on the provision of a working political-institutional context: a calculable law and administration to guarantee property rights and contract; a cohesive and insulated decision-making structure backed by a differentiated, specialized, and competent bureaucracy; a physical infrastructure of transport and communication links with domestic and global markets; and sustained government investment in human capital, namely health, welfare, and education, to guarantee a skilled and productive work force.

Thus, the major task for many low-income countries is not simply to improve incentives through the market mechanism by reducing the role of the state, but also to augment and strengthen the efficacy of state institutions so that they can maintain an enabling environment and assume a directive and coordinating role in economic life. Such a "developmental state" will have the institutional capacity to provide macroeconomic stability and supply the public goods that allow a market economy to emerge and function in the first place. Furthermore, it is not clear that a drastic reduction of the state's role in the economy will automatically produce greater efficiency and enhance economic performance. In India, and indeed in many parts of the developing world, there exists a high degree of interdependence between the public and private sectors. Arbitrary and 
rash deregulation or privatization in the absence of viable alternatives will only exacerbate socioeconomic dislocations.

This call for state involvement should not be misinterpreted as an endorsement of indiscriminate regulation and intervention. What really matters is not the extent but the quality of state intervention. Here it is appropriate to ask why the interventionist Indian state, which also acted as a demiurge, failed to produce the economic achievements of the East Asian NICs. Contrary to conventional wisdom, the answer has little to do with democratic versus authoritarian rule, but rather with the complex relationship between states and markets. While the Indian state continued to expand its role as regulator, producer, and distributor throughout the 1960s and 1970s, including sheltering both public and private sector producers from market competition, the South Korean and Taiwanese states were using the leverage they gained from control over financial flows to encourage market competition. They expanded export-processing zones and private sector investment, for example, by providing incentives to firms and individuals to invest in stock ownership in privatized state firms, while at the same time removing the state from speculative and unproductive economic activities.

In the end, India's strategy of import substitution, rather than a policy of protecting infant industries, was a way of protecting inefficient and monopolistic producers. Moreover, the Indian state in adopting what Jagdish Bhagwati has aptly termed a "proscriptive economic regime," 16 quite unlike the "prescriptive policies" of the economically successful East Asian countries, failed to direct the economy via market signals. Proscriptive policies not only grant politicians and bureaucrats the power to say no to most private initiatives, they also provide opportunities for self-aggrandizement by spawning quasi-monopoly rents (in the form of political contributions and black money), licenses, and built-in inefficiencies. Hence, it is the quality of state intervention and selectivity in targeting that separates the Indian state from the East Asian NICs.

Finally, the East Asian experience suggests that if the fruits of marketoriented growth are to have positive effects on redistribution and poverty alleviation, extensive state commitment and intervention are required. The neoclassical prescription of relying on the "Pareto Optimum" is untenable since under imperfect conditions, the market equilibrium is in general not Pareto efficient. As Amartya Sen has aptly noted, "a state can be Pareto optimal with some people in extreme misery and others rolling in luxury."17

16. Jagdish Bhagwati, Protectionism (Cambridge: Cambridge University Press, 1988).

17. Amartya Sen, On Ethics and Economics (Oxford: Basil Blackwell, 1987), p. 32. 
Similarly, the claim by some neoclassical analysts that economic liberalism and political democracy are incompatible and therefore economically liberalizing but politically authoritarian regimes are required (and justified) to achieve certain developmental objectives, is not only problematic but unacceptable on both normative and practical grounds. ${ }^{18}$ First, there is no clear correlation between "regime type" and economic performance, and in the case of India any type of authoritarian rule will only exacerbate the problems of governability. ${ }^{19}$ Yet, market-conforming economic reforms mean the elimination of subsidies, the phasing out of price and wage controls, and in general an overall reduction in the state's distributive intervention in the economy. All these "bitter medicine" measures mean enduring more pain, socioeconomic dislocation, and a rise in social and political tensions. In such an environment, democratic regimes with their legitimate authority can most effectively mediate between the conflicting factions within civil society, especially between capital and labor. This irony, what Miles Kahler calls the "orthodox paradox," 20 means that for governments to reduce their role in the economy and expand the arena of market forces, the state itself must first be strengthened.

18. The most forceful exponent of this view is D. Lal, The Hindu Equilibrium: Cultural Stability and Economic Stagnation, India c. 1550 B.C.-A.D. 1980 (London: Clarendon Press, 1988). However, similar conclusions have been reached by some Marxist scholars, e.g., G. O'Donnell, Modernization and Bureaucratic Authoritarianism: Studies in South American Politics (Berkeley: Institute of International Studies, 1973).

19. It has been convincingly argued that in India, economic performance has been only marginally affected by the type of regime in power. See Lloyd H. Rudolph and Susanne H. Rudolph, In Pursuit of Lakshmi: The Political Economy of the Indian State (Chicago: Chicago University Press, 1987); also, Atul Kohli, Democracy and Discontent: India's Growing Crisis of Governability (New York: Cambridge University Press, 1990).

20. Miles Kahler, "Orthodoxy and its Alternatives: Explaining Approaches to Stabilization and Adjustment," in Economic Crisis and Policy Choice: The Politics of Adjustment in the Third World, Joan Nelson, ed. (Princeton: Princeton University Press, 1990), p. 55. 